\title{
THE INTANGIBLE REPORTING CULTURE OF THE LARGEST HUNGARIAN COMPANIES'
}

\author{
A content analysis based study \\ Zsuzsanna Ilona Kovács - Edit Lippai-Makra- \\ Gábor Dávid Kiss - István Deák ${ }^{2}$
}

\begin{abstract}
Based on the method of content analysis, our study focused on the intangible reporting culture of the companies on the list of the thirty largest Hungarian companies in both 2012 and 2017. The results have shown the scores showed a very moderate average increase between the two business years examined, which is significantly less than the growth rates found in literature. The sample entities communicated most intensively about intellectual property, goodwill, and other intangible items, as well as environmental and other factors. Based on the robust regression model presented, the following factors had significant influence on the quality of the financial statements in 2017: public listing, sector, and sales.
\end{abstract}

JEL code: $\mathrm{M}_{41}$

Keywords: intangible assets, voluntary reporting, robust regression, content analysis

1 This research was supported by the project nr. EFOP-3.6.2-16-2017-00oo7, titled Aspects on the development of intelligent, sustainable, and inclusive society: social, technological, innovation networks in employment and digital economy. The project has been supported by the European Union, co-financed by the European Social Fund and the budget of Hungary.

2 Zsuzsanna Ilona Kovács, $\mathrm{PhD}$, assistant professor, University of Szeged, Faculty of Economics and Business Administration, PNGKI, Szeged. E-mail: zsuzsanna.k@eco.u-szeged.hu.

Edit Lippai-Makra, assistant lecturer, University of Szeged, Faculty of Economics and Business Administration, PNGKI, Szeged. E-mail: makra.edit@eco.u-szeged.hu.

Gábor Dávid Kiss, $\mathrm{PhD}$, associate professor, University of Szeged, Faculty of Economics and Business Administration, PNGKI, Szeged. E-mail: kiss.gabor.david@eco.u-szeged.hu.

István Deák, $\mathrm{PhD}$, associate professor, University of Szeged, Faculty of Economics and Business Administration, PNGKI, Szeged. E-mail: deak@eco.u-szeged.hu. 


\section{INTRODUCTION}

Stakeholders expect business entities to provide them with relevant information to support their investment and lending decisions including information on intangible assets. The regulations of financial reports are laid down to attain uniform communication with the stakeholders detailing its methodology and the minimum content required to be provided for third parties. In addition to the minimum content, however, companies may and do publish data voluntarily. They are prompted by the belief that the cost of producing the information will be exceeded by the benefit achieved. Shehata (2014) has summed up the economic theories linked to the part played by voluntary reporting in the economy: agency theory, signalling theory, capital need, and legitimacy theory. The author regards voluntary disclosure in reports on top of the obligatory information as a way of managing the problem, as it assists to mitigate the asymmetry of information between shareholders as principals and managers as agents.

Boda et al. (2019) are of the view that non-industrial sectors based on knowledge content play a decisive part in sustainable development side by side with structural transformation and industrial development. Petty et al. (2009) present a consensus has been achieved on breaking down intellectual capital into three large sets: human, internal, and external capital. Sveiby (2001) uses the term 'invisible balance sheet' to describe intangible assets he categorises as follows:

- Human structure: individual competences, abilities, qualifications, experience

- Internal structure: patents, theories, models, IT systems, corporate culture

- External structure: buyer and supplier relationships, trademarks, trade names, reputation, image (Sveiby, 2001:64-66).

The current standards of financial reports leave little room for intangible assets to appear in company balance sheets. It is true both for the Hungarian and the international accounting standards albeit for different reasons. In this country a rulebased approach is required by law; the items to be recognised are detailed and their content regulated. International financial reporting standards (IFRS) apply a principle-based approach using definitions and recognition criteria to narrow the scope. Whichever regulation you take it is evident the scope of intangible resources used by enterprises is much larger than what you can read in financial reports. Standard setters have been widely criticised for this reason, and professionals have been arguing for a long time whether enlarging the group of balance sheet asset items would be a better solution or just the opposite: it would be a mistake to recognise assets with uncertain return. The arguments for capitalization can be supported by the principle of completeness and relevance: the stakeholders using the reports need a complete set of information, including all factors 
that may have an impact on decision making. On the other hand, reliability is required, i.e., the figures in the reports should be based on 'objective' measuring techniques, free of errors and distortions. As a result, you must charge internally generated intangible assets against the income of the current year. Recognition as expenses will not result in the inclusion of assets with uncertain return in a report, but Lev (2003) has warned that a seemingly conservative approach, i.e., recognition as expenses and underestimation of the profit may generate an opposite effect in other periods, i.e., it may lead to 'aggressively' inflated profits later on. EFRAG (European Financial Reporting Advisory Group) representing the 'European' view in standard setting have recently published a comprehensive study on the topic, which is closed by the statement we have arrived to a paradoxical situation regarding intangible assets. On the one hand, they drive the economy as a motor assisting value creation. On the other hand, they render the system vulnerable due to their uncertainty, low grade of stability and risky nature (Zambon et al., 2020).

Brand Finance (2018:24-25) provides a measure of off-balance sheet items for business year 2017: intangible assets made up for 52 per cent of the global enterprise value of all the world's listed companies including 7 per cent for goodwill, 5 percent for disclosed and 40 percent for undisclosed values. According to observations in Hungary, it is not different in this country either. An analysis by Juhász (2016) based on a wide range of questionnaires has found, company executives believed half of the value of their companies is not reflected in their book values. Nevertheless, off balance sheet items must be known for decision making, since total assets must be understood to carry out benefit calculations to determine where and how you must intervene in the operations (Laáb, 2010). Saxné Andor (2014) made an empirical research among Hungarian companies on the application of accounting regulations related to intangible assets. The research covered the areas of recognition in the balance sheet, year-end evaluation, and mandatory and voluntary disclosure in the notes. It has been found Hungarian enterprises failed to recognise most intangible assets used for their operations in their reports because of the relevant regulations.

Getting a clear picture is rather difficult as there are several terms in the literature to describe extra items such as intellectual capital, human capital, or knowledge capital. The items listed above are often used with different content, so any specific concept is only used in this study when citing other authors' ideas. The assets meeting the recognition criteria will be termed 'intangible assets', while 'intangible resources or items' will denote a wide range of items that are not material in nature, but are part of business resources in a broader sense and are not necessarily in the balance sheet. The term 'knowledge assets' will be used with reference 
to a wide range of intangible resources based on knowledge in some way that are important for enterprises but do not meet the criteria of balance sheet items.

Orhangazi (2019) believes intangible items play a special part as they allow profit increase without the necessity of involving further physical capital. The author advises that the possession of patents, trademarks, trade names and other rights linked to intellectual property places companies into strong positions, it can establish monopolies and allows for optimum pricing of their products - much higher than their production costs. Possession of the latter may boost the value of their shares for investors, i.e., the information on intangible assets reported by enterprises is useful for stakeholders. Gambetti et al. (2017) have underlined a strong market position carries both power and responsibility, emphasising the importance of ethical management of intangible assets. Accordingly, responsible enterprises must have continuous dialogue with their stakeholders. Their communication is aimed to maintain an alliance in which a corporation and its stakeholders build and possess intangible assets including corporate identity, brand and reputation as its most important components based on joint values and goals. Such dialogue or information may use several channels including the notes to financial reports, i.e., in the attachments to quantified reports or in management reports.

Following a summary of the results of similar studies in literature, we present in this study our empirical analysis of the reporting practice related to intangible assets of the largest Hungarian enterprises based on an international methodology. The earlier and current phases of our research cover business years 2012 and 2017, which allows for the observation of evolution over time.

\section{FINDINGS OF EARLIER RESEARCH}

If enterprises opt for voluntary reporting, they must select a communication channel for the purpose. They can publish information in the notes to financial reports, in management reports or in separate documents. According to a survey by KPMG (KPMG International, 2020:12), 77 per cent of the largest European companies publish social responsibility reports, but the continent is not uniform. Although the ratio is lower in Eastern Europe, there has been significant improvement over the past three years, while growth has slowed down in Western Europe. The voluntary reports published by corporations may include a wealth of information on intangible resources (for instance, on the management of human resources or the quality of buyer and supplier relationships), but - unlike financial reports - they do not result in comparable information for stakeholders that are available for each business year. Enterprises may in future present financial data and non-financial factors in the same report, however, you will still have 
to wait for the spread of integrated reporting. Until it becomes universal, financial reports remain the only report packages available for stakeholders which are regularly published and are compiled on comparable bases.

Irrespective of regulations, you cannot deny that intangible resources are extremely valuable for enterprises for several reasons. Castilla-Polo-Ruiz-Rodríguez (2017) advises they are valuable because they supplement each other, they are irreplaceable and cannot be duplicated. All that means that traditional accounting and controlling approaches may not work in their case. Accordingly, enterprises have found a way to inform their stakeholders about such phenomena in the notes to the reports or in the form of other reports. The number of publications on the social role of companies, on the principles of company governance or on sustainable operation (so termed ESG reports) has multiplied over the past decade. Most studies, however, do not analyse those channels but are restricted to financial reports as they are compiled on uniform bases, are accessible and provide a good approximation on how communicative enterprises are regarding their intangible assets (OECD, 2012).

According to Albu et al. (2017), financial reporting infrastructure needed to improve significantly in the countries of the Central and Eastern European region, so studying the reporting culture of the countries is important. The authors go on to say that, subject to the issues studied and the types of data used, the findings of studies focusing on one country may be regarded as 'unique' case studies or examples to describe countries with a similar institutional background.

Novák (2018) studied intangible reporting practices with respect to IAS 38 rules. Analysing a sample of listed Czech companies, he found the level of disclosure was low - mostly manufacturing enterprises met the requirements. Oliveira et al. (2006) made a content analysis-based survey in European environment: they studied disclosure by 56 listed Portuguese companies for business year 2003. Out of the three groups of intellectual capital as defined in literature, information on human capital was the least reported compared to the categories of structural and relational capital. $\mathrm{Li}$ et al. (2008) also focused on the same three categories analysing the connection between governance structure and disclosure of intellectual capital. Their sample consisted of 100 companies listed on the London Exchange covering seven industrial sectors. The annual reports of the enterprises published from March 2004 to February 2005 were made subject to a sophisticated content analysis, which - in addition to the presence or failure of reporting - reflected its intensity and allowed for finding the items in focus. The authors have found interconnection between reporting on intellectual capital and independent variables such as the composition of the board of directors, ownership structure, the size of the audit committee and the frequency of its meetings. 
Other authors have taken over the index compiled by Li et al. (2008) - the list of items traced in annual reports. Boujelbene-Affes (2013) studied listed French enterprises and found interconnection between reporting on intellectual capital as an independent variable and capital cost as a dependent variable. The authors differentiated high-tech companies from traditional industries, and they also found significant negative correlation between capital cost and reporting on the two components of intellectual capital. (human and structural capital). Bogdan et al. (2011) also used Li's method analysing 19 companies listed on the Bucharest exchange for five years (2005-2009). According to the authors, although general reporting scores increased during the period studied, the reporting activity of the companies in the sample was low. Petty et al. (2009) believe the most important obstacle to the compilation of large number of reports is the lack of consistency of the methods of reporting and the difficulty of assigning relevant quantitative values to the different categories.

Ho et al. (2012) studied the Hong Kong exchange to analyse the interconnection between initial public offering (IPO) of enterprises and the disclosure of intellectual capital components. Based on the sample selected for the period 2008-2010, it was found there was significant positive correlation between disclosure and investor confidence. Empirical analyses support the view that enterprises benefit from communication with their stakeholders as investors appreciate the extra information provided.

Our own analysis to be detailed later is based on one research discovered in international literature, so the findings of the author are presented here in more detail. Ragini (2012) analysed the annual reports of Indian, US and Japanese companies for five years (2001-2005) to identify the intangible items in them. The sample consisted of the largest US (100), Indian (100) and Japanese (60) companies, but the actual calculations were made from a lower number of reports, as the records were not always accessible. Ragini identified 180 intangible items and counted the ones information was provided on in the different reports.

The items were categorised as follows:
a) research and development (20 items),
b) strategy and competition (30 items),
c) market and customer (36 items),
d) human resources (26 items),
e) intellectual property rights, goodwill, and other intangible assets (25 items)
f) corporate and shareholder information (18 items),
g) environmental and other intangible factors ( 25 items). 
She concluded from her findings that the average value of scores continuously increased for five years in the three countries studied. Except for 2001, the average of the US companies was always the highest. The Indian companies came second except for 2005 when the Japanese average was the second highest. Regarding the nature of reporting, Indian companies most focused on research and development and human resources, US ones published an outstandingly high amount of data on strategy and competition, market and customer and intellectual property, while Japanese enterprises focused on corporate and shareholder information and environmental factors. In her analysis, the author has tried to find interconnection between the scores achieved by the different companies and factors, such as company size, profitability, leverage, the ratio of its book value and market value or industry type. Based on her findings, she has stated the scores achieved are influenced by company size and profitability in the case of Indian companies; by industry type for US enterprises and by company size for Japanese companies (Ragini, 2012).

\subsection{Theoretical model}

You can see in literature the evolution of reporting on intangible assets $(S)$ is subject to the following factors: the size of a company (net sales) and income (profit before tax $(E K)$, asset composition $(E)$, public listing $\left(d_{-} t\right)$ and the sector $\left(d_{-} I\right)$ it is operating in, so, the following theoretical model has been set up (1):

$\ln S=$ const. $+\beta_{1} \ln E K+\beta_{2: k} \ln E+\beta_{k+1} d_{t}+\beta_{k+2: n} d_{-} I+\varepsilon$

where $\varepsilon$ is non-autocorrelated, normally distributed random error.

We used the logarithmic value of net sales $\left(E K_{N A B}\right)$ for company size, while income can be described using the logarithmic value of profit before tax $\left(E K_{A E E}\right)$. Asset structure was analysed using the logarithmic value of intangible assets $\left(E_{I J}\right)$, or their value in proportion to balance sheet total. $\left(E_{\frac{I J}{M F O}}\right)^{3}$. For industrial categorisation, due to statistical considerations, we differentiated companies operating in the machine industry and steel production $\left(d_{-} I_{g}\right)$ from those manufacturing electronical and telecommunication products $\left(d_{-} I_{e}\right)$. In line with the expectations related to random error, the different alternative models were compared resulting in the following (2) theoretical model used for our calculations:

$\ln S=$ const. $+\beta_{1} \ln E K_{N A B}+\beta_{2} \ln E_{I J}+\beta_{3} \ln E_{I J}+\beta_{4} d_{-} t+\beta_{5} d_{-} I_{g}+\beta_{6} d_{-} I_{e}+\varepsilon$

3 Net sales, profit before tax, balance sheet total and intangible assets were given in HUF on the basis of the reports. 
The following intuitive expectations can be presented related to the different coefficients: higher value of sales (based on Ragini (2012), and significant intangible assets (based on Lippai-Makra et al. (2019) motivate companies to publish more detailed reports, since non-financial items have major significance in the value of a company.

\section{EMPIRICAL ANALYSIS}

We selected our samples based on an earlier research of ours (Kovács, 2015): we took the companies on a TOP 200 list compiled by Figyelö (Figyelö, 2013), and our goal was to analyse the individual reports of the 30 largest companies based on their net sales in 2012 applying the Ragini method (At that time annual reports were uniformly compiled subject to the rules of the Accounting Act and were available in 29 cases). Completing the former analysis, the following statements could be made:

1. Reporting on intangible assets by companies in the Hungarian sample was defined by presenting content mandatorily required in notes to the reports.

2. Voluntary reports and data were published by publicly listed companies that also attached business reports to their annual reports.

In the current phase of our research, we analysed the reports by companies that had been included in the 2012 sample and were still among the largest 30 by their net sales in 2017 (Figyelö, 2018), in other words, they retained their place among the largest enterprises. Year 2017 was selected because that was the latest available set of data at the beginning of this phase of the research (you can see in studies using similar methods referred to above that several years usually pass from a period studied to the publication of the findings). Thus, sampling was purposive, like in studies analysing the reporting culture of different countries mentioned in Chapter 2: companies were selected in line with a given parameter (for instance, listed companies, companies with the highest sales). Annual reports of 2017 by listed companies were compiled subject IFRS pursuant to article 9/A of the Accounting Act. We checked if the business reports of all enterprises were available online. In addition to the three listed companies, where it was mandatory subject to the rules, one more enterprise published its annual report on the internet also including the business report.

We again used the Ragini method for content analysis, so the scores of the $17 \mathrm{com}$ panies in the sample could be compared both to each other and to their earlier scores. 
Company scores were based on the number of intangible items found in their reports also calculated in percentage form as follows:

score $=\frac{\text { number of intangible items in a given report }}{\text { maximum number of items in a report }(180)} \times 100$

From now on, the scores assigned to the reports shall be the scores calculated using the above method, which shall be a value from o to 100 in all cases. Content analysis, the tool we selected, is widely used for studying the disclosure of intangible items and reporting culture following Castilla-Polo-Ruiz-Rodríguez (2017). The authors also mention two forms of execution: computerised and manual coding. The former has the advantage of objectivity, but Bellora-Guenther (2013) argues for manual coding, since the reading and interpretation of the content of reports by people is indispensable for considering the context. Therefore, this research was made by reading and 'manually' scoring the reports comparing the 2012 and the 2017 ones.

Ragini's findings have shown the average score of the reports by Indian corporates increased by 7 per cent, that of US companies by 9 per cent and of Japanese companies by 12 per cent from 2001 to 2005 (Table 1). Provided the same rate of increase has continued in the years after the study, the scores may have become significantly higher by now.

Table 1

Ragini's findings

\begin{tabular}{cccc}
\hline Country & $\mathbf{2 0 0 1}$ & $\mathbf{2 0 0 5}$ & $\begin{array}{c}\text { Average annual } \\
\text { growth }^{\star}\end{array}$ \\
\hline India & 16.38 & 21.47 & $7.0 \%$ \\
USA & 16.01 & 22.74 & $9.3 \%$ \\
Japan & 14.05 & 22.38 & $12.7 \%$ \\
\hline
\end{tabular}

Source: Ragini (2012:58)

Note: *average annual growth is own calculation.

The average of the Hungarian sample comprising 17 companies was 25.3 in 2012 and 28.9 in 2017 (Table 2). It is true for both years analysed that the median should be considered due to high deviation, which was 19 and 22, respectively. The simple arithmetic average of the scores of Hungarian companies increased by a mere 2.7 per cent p.a. from 2012 to 2017 on average. 
Table 2

Statistical parameters of the Hungarian sample

\begin{tabular}{lcc}
\hline Parameter/Period & $\mathbf{2 0 1 2}$ & $\mathbf{2 0 1 7}$ \\
\hline Average & 25.3 & 28.9 \\
Deviation & 15.1 & 19 \\
Median & 19 & 22 \\
Minimum & 11 & 14 \\
Maximum & 59 & 69 \\
\hline
\end{tabular}

Source: own calculation

In 2017, the highest values were found in the reports by companies that, being listed, also published business reports - their average was 65.74. It is clear they disclosed information on their intangible resources much exceeding the average of the sample (Figure 1). You can again see voluntarily disclosed information, which significantly exceeded minimum requirements, was typical for market listed companies that compiled IFRS reports and published their business reports online. In 2017 you can find one company that is not market listed, nevertheless, it made its business report public online.

\section{Figure 1}

Scores assigned to the reports of enterprises

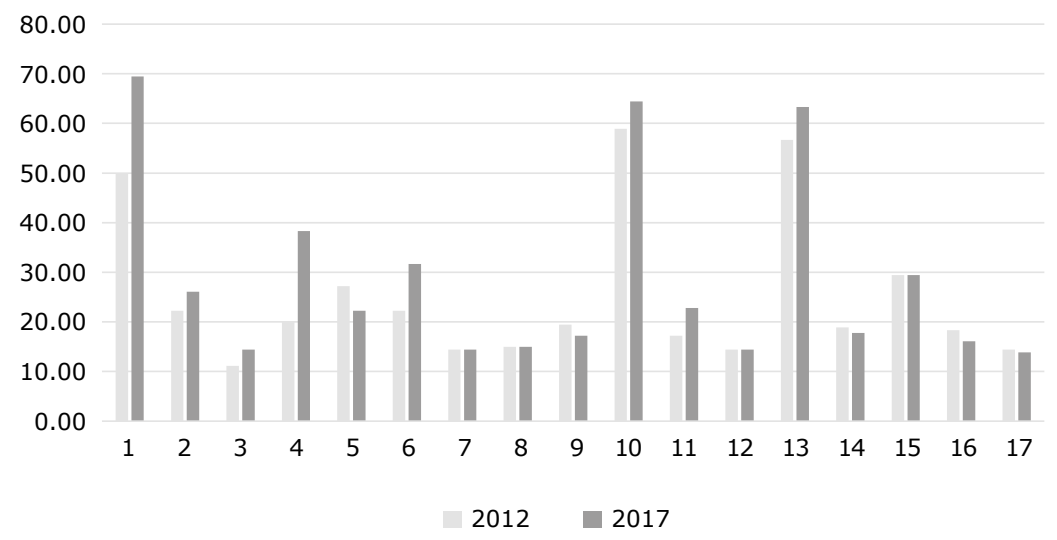

Source: own design

Note: listed companies: $\mathrm{nr}$ 1, 10, 13; published business report for 2017 online: $\mathrm{nr} 4$. 
Minimum values were similar in both years studied and they appeared in the reports of non-public companies applying the provisions of the Accounting Act. There were no values approximating zero, since pursuant to regulatory requirements, all companies must reach a minimum score if they compile annual reports subject to legal requirements. It is difficult to identify a uniform minimum value, since, for instance, listed companies are subject to specific rules and business reports are not always accessible online. In an earlier phase of our research, we identified 14.44 as a minimum value - excluding the content of business reports (for more details, see: Kovács, 2015, pp. 235-236). Thus, there is a set of items providing the 'backbone' of the information published that occur frequently. If you take the four enterprises also publishing business reports for 2017 out of the sample, the average was 19.66, which did not much exceed the minimum value stipulated in the Accounting Act (in the quantified sections and the notes).

Next, you can find the result of our calculations related to the groups of items generated by Ragini. Group level calculations allowed us to analyse the nature of the information provided by enterprises for their stakeholders. We could also review how disclosure relating to different topics changed in the Hungarian sample.

\subsection{Group level calculations}

Breaking down the items into groups allows further analysis to reveal the types of intangible items given more weight in the reports of the enterprises in the Hungarian sample and the changes of the relevant trends over the past five years (Figure 2). The companies in the sample reported most on intellectual property, goodwill, intangible assets in their balance sheets and environmental and other factors in both years. 


\section{Figure 2}

Average number of items in Hungarian reports by categories

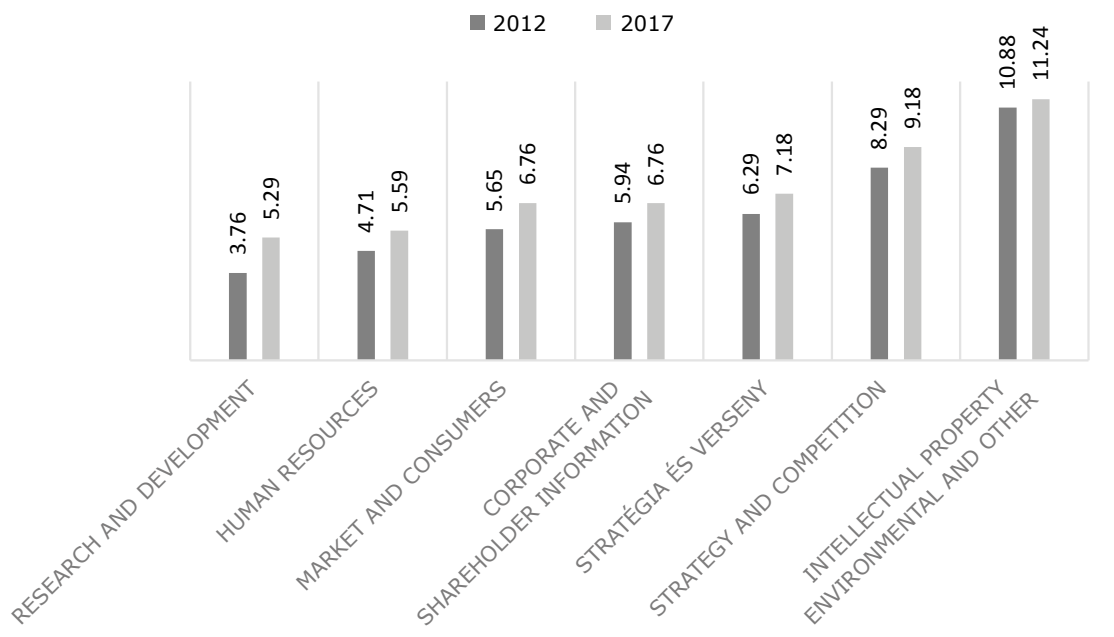

Source: own design

Nevertheless, 6-7 items from categories 'market and customers', 'corporate and shareholder information' and 'strategy and competition' were included in the reports although the number of mandatory items there was minimum. Enterprises were least communicative about human resources and research and development - probably because communication is riskiest in those areas.

The 2012 values were close to those five years later. Research and development produced the highest growth in the period studied. There were no categories reflecting decline, environmental information produced the lowest positive change, though it was the category holding the highest average anyway. The number of reported items in the other sets in the middle range increased by close to one on average. All that means the difference between the different categories was reduced, i.e., reports had become more balanced over time.

We have studied the relatively frequent items appearing in more than half of the reports as well as the information attached in almost all cases (Table 3). Studying the most frequent items, the effect of the Accounting Act is obvious; in almost all cases it is the mandatory content required in the quantitative section and the notes to the reports that is published. 
Table 3

The most frequent items

\begin{tabular}{|c|c|c|c|}
\hline $\begin{array}{l}\text { Ragini's (2012) } \\
\text { categories }\end{array}$ & $\begin{array}{c}\text { Published in at least } 9 \\
\text { reports }\end{array}$ & \multicolumn{2}{|c|}{ Published in at least 16 reports } \\
\hline $\begin{array}{l}\text { Research and } \\
\text { development }\end{array}$ & $\mathrm{R} \& \mathrm{D}$ expenditure & \multicolumn{2}{|c|}{-} \\
\hline $\begin{array}{l}\text { Strategy and } \\
\text { competition }\end{array}$ & - & \multicolumn{2}{|c|}{-} \\
\hline \multirow{2}{*}{$\begin{array}{l}\text { Market } \\
\text { and customers }\end{array}$} & Major products & \multicolumn{2}{|l|}{ Földrajzi eloszlás } \\
\hline & \multicolumn{3}{|l|}{$\begin{array}{l}\text { Marketing/ } \\
\text { Advertising costs }\end{array}$} \\
\hline \multirow{3}{*}{ Human resources } & \multirow{3}{*}{$\begin{array}{l}\text { Number of Employees } \\
\text { (segment-wise) }\end{array}$} & \multicolumn{2}{|l|}{ Number of Employees } \\
\hline & & \multicolumn{2}{|c|}{$\begin{array}{l}\text { Particulars of remuneration and benefits } \\
\text { paid to key to managerial personnel }\end{array}$} \\
\hline & & \multicolumn{2}{|c|}{ Information about executive officers } \\
\hline \multirow{7}{*}{$\begin{array}{l}\text { Intellectual property, } \\
\text { goodwill, and other } \\
\text { intangible assets }\end{array}$} & \multirow{7}{*}{$\begin{array}{l}\text { Accounting treatment } \\
\text { for goodwill and other } \\
\text { intangible assets }\end{array}$} & \multicolumn{2}{|c|}{ Value of intellectual property rights } \\
\hline & & \multirow{2}{*}{$\begin{array}{l}\text { Other intangible } \\
\text { assets }\end{array}$} & Value \\
\hline & & & Items included \\
\hline & & \multirow{4}{*}{$\begin{array}{l}\text { Goodwill and Other } \\
\text { Intangible Assets }\end{array}$} & $\begin{array}{l}\text { Amortization } \\
\text { method }\end{array}$ \\
\hline & & & $\begin{array}{l}\text { Amortization } \\
\text { period }\end{array}$ \\
\hline & & & Amortized value \\
\hline & & & Carrying value \\
\hline \multirow{3}{*}{$\begin{array}{l}\text { Corporate and } \\
\text { shareholder } \\
\text { information }\end{array}$} & Corporate history & \multicolumn{2}{|l|}{ Corporate profile } \\
\hline & Number of shareholders & \multicolumn{2}{|c|}{$\begin{array}{l}\text { Shareholding distribution } \\
\text { (type of shareholders) }\end{array}$} \\
\hline & $\begin{array}{l}\text { Shareholding distribution } \\
\text { (number of shares held) }\end{array}$ & \multicolumn{2}{|l|}{ Major shareholders } \\
\hline \multirow{6}{*}{$\begin{array}{l}\text { Environmental } \\
\text { and other factors }\end{array}$} & $\begin{array}{l}\text { Environmental } \\
\text { commitments }\end{array}$ & \multicolumn{2}{|c|}{ Contingencies and commitments } \\
\hline & Environmental matters & \multirow{5}{*}{\multicolumn{2}{|c|}{ Related party transactions }} \\
\hline & Environmental expenditure & & \\
\hline & $\begin{array}{l}\text { Products/technologies } \\
\text { contributing to } \\
\text { environment }\end{array}$ & & \\
\hline & $\begin{array}{l}\text { Off-balance sheet } \\
\text { arrangements }\end{array}$ & & \\
\hline & Contractual obligations & & \\
\hline
\end{tabular}

Source: own design 
Our findings suggest that disclosure of intangible resources by Hungarian enterprises is strongly influenced by the regulations in the Accounting Act. Next, we attempted to find if there were any other factors having a substantive effect on disclosure.

\subsection{Regression model}

We compared two periods (years 2012 and 2017) in our study using regression models on logarithmic data. The number of available companies restricted the size of the sample, therefore, we used robust regression, which is more practical for analysing small samples, rather than the traditional method of ordinary least squares (OLS). To justify our approach, first we sum up the statistical dilemmas in the application of OLS and then introduce robust regressions pointing out how they can be used to resolve the dilemmas.

In general, the Gauss-Markov theorem is used for regressions, stating the linearity of $\beta_{p}$ parameters, the randomness of sample taken from population $N$ (the criteria of belonging to the sample are well defined, the variables are independent and identically distributed), with conditionally mean zero and homoscedasticity of the error (Wooldridge, 2010). Using the method of ordinary least squares (OLS), the following linear regression (3) can be generated from independent variable $p$ :

$y_{i}=\beta_{0}+\beta_{1} x_{i 1}+\cdots+\beta_{p} x_{i p}+\varepsilon_{i}, i=1,2, \ldots, n$,

where the size of errors defines fitting the model, while points far away from the regression line are termed outliers. However, securing that error $\varepsilon_{i}$ be uncorrelated and identically distributed is a major methodological challenge due to the small size of the sample, which is the result of the nature of content analysis used. In the case of a traditional OLS regression, it would result in distorted coefficients and false significance that could be somewhat compensated using dummy variables referring to public listing and industrial sectorisation. The use of logarithmic data is traditionally regarded robust because of time series scaling, but it can, in fact, increase diversity unless the time series generated assume normal distribution Feng et al. (2014), i.e., the problem of outliers is not solved. In practice, however, neither that nor ridge regression provided an outcome with nonautocorrelated error, while quantile regression by $\tau=0.5$ in the sample failed to be proved the right decision from the aspect of diagnostics (neither QSE, not SQ tests proved to be significant) probably due to the high number of outliers.

The family of robust regressions, which are popular for the analysis of small samples, offers a solution to manage the distortion caused by outliers, as it replaces 
the criterion of minimising the sum of square errors $\hat{\beta}=\min _{\mu \in \mathrm{R}} \sum_{i=1}^{n}\left(y_{i}-\mu\right)^{2}$ with a procedure less influenced by outliers. The $M$ estimation is such a procedure, where we use the robust maximum likelihood estimation introduced by Kornacki-Bochniak (2015) for outliers (Susanti et al., 2014). In it, the estimation of $\hat{\beta}=\beta_{n}\left(x_{1}, x_{2}, \ldots, x_{n}\right)$ coefficients is free of distortion and of minimum variance, and it is based on the method of iteratively reweighted least squares (IRLS) (4):

$\sum_{i=1}^{n} x_{i j} w_{i}\left(y_{i}-\sum_{j=0}^{k} x_{i, j} \beta\right)=0, j=0,1, \ldots, k$.

Annex 2 details the path leading to the definition of weighting function $w_{i}$. Applying the $\mathrm{M}$ estimation, we minimise function $\rho$ of the variations rather than the traditional minimisation of the sum of least square deviations ${ }^{4}$. The latter will increase at a lower rate than square functions, which can reduce the burden of major deviations on the estimations without reducing sample size (Csendes, 2015; Takács, 2012). Repeating parameter estimations, we get to the convergent values for coefficient $\hat{\beta}_{M}$. A disadvantage of the procedure is the lack of assumptions related to the distribution of errors (Rousseeuw-Yohai, 1984). On the other hand, Yang et al. (2019) do recommend the method for the analysis of heavy-tailed and asymmetrical data, since several algorithms are available today for estimating location and scale parameters. (Csendes, 2015; Fegyverneki, 2003). The models were fitted using software Eviewsi1.

\subsection{Findings}

We have found material difference between 2012 and 2017 as the significance of intangible assets had been reduced to near zero (or even negative) side by side with the importance of net sales becoming positive (Table 4). In addition, sector differences had become important in the reporting practice of the companies in the sample by 2017. Further, the higher level of weight of intangible assets in proportion the balance sheet total had been less associated with more willingness for disclosure earlier, while its significance seemed to diminish by 2017 . In the case of large Hungarian corporates with the highest stable revenues, net sales side by side with public listing, had become decisive from the aspect of the quality of the information content of their reports, while balance sheet structure had only a minor part to play.

$4 \hat{\beta}_{M}=\min _{\beta} \sum_{i=1}^{n} \rho\left(\frac{e_{i}}{\sigma}\right)=\min _{\beta} \sum_{i=1}^{n} \rho\left(\frac{y_{i}-\sum_{j=0}^{k} x_{i, j} \beta_{j}}{\sigma}\right)$ 
Table 4

Results received using the method of robust least squares (M estimation)

\begin{tabular}{|c|c|c|c|c|c|c|c|c|}
\hline Year & \multicolumn{4}{|c|}{2012} & \multicolumn{4}{|c|}{2017} \\
\hline variable & coeff. & $\begin{array}{l}\text { stat. } \\
\text { error }\end{array}$ & z-stat. & $\mathrm{P}$ & coeff. & $\begin{array}{l}\text { stat. } \\
\text { error }\end{array}$ & z-stat. & $\mathrm{P}$ \\
\hline constant & 1.90 & 0.97 & 1.95 & 0.05 & 1.66 & 0.34 & 4.87 & 0.00 \\
\hline $\ln E K_{N A B}$ & -0.21 & 0.12 & -1.77 & 0.08 & 0.10 & 0.03 & 3.48 & 0.00 \\
\hline $\ln E_{I J}$ & 0.30 & 0.09 & 3.22 & 0.00 & -0.04 & 0.01 & -6.75 & 0.00 \\
\hline $\ln E_{\frac{I J}{M F O}}$ & -0.28 & 0.10 & -2.85 & 0.00 & -0.02 & 0.01 & -3.53 & 0.00 \\
\hline$d \_I_{t}$ & 0.82 & 0.18 & 4.51 & 0.00 & 1.65 & 0.04 & 39.55 & 0.00 \\
\hline$d \_I_{g}$ & 0.07 & 0.13 & 0.56 & 0.58 & 0.57 & 0.04 & 14.82 & 0.00 \\
\hline$d \_I_{e}$ & 0.02 & 0.13 & 0.14 & 0.89 & -0.27 & 0.04 & -7.42 & 0.00 \\
\hline \multicolumn{9}{|c|}{ robust statistics } \\
\hline Square $\mathrm{R}$ & 0.50 & & & & 0.65 & & & \\
\hline Square Rw & 0.97 & & & & 1.00 & & & \\
\hline Jarque-Bera & 4.97 & & & 0.08 & 12.16 & & & 0.002 \\
\hline Q test & 0.991 & & & 0.318 & 0.3823 & & & 0.536 \\
\hline $\begin{array}{l}\text { homo- } \\
\text { scedasticity }\end{array}$ & 0.0187 & & & 0.891 & 0.1566 & & & 0.692 \\
\hline \multicolumn{9}{|c|}{ non robust statistics } \\
\hline $\begin{array}{l}\text { Dependent } \\
\text { variable } \\
\text { average }\end{array}$ & 3.10 & & & & 3.20 & & & \\
\hline $\begin{array}{l}\text { standard } \\
\text { error reg. }\end{array}$ & 0.35 & & & & 0.47 & & & \\
\hline
\end{tabular}

Source: own design using software Eviews11

Note : weighting $=$ Bi square, scale $=$ MAD (median centred), weighting calculated by diagonal of the hat matrix

Errors were not autocorrelated (Q-test) and had no heteroscedasticity, so the estimation of the coefficients cannot be deemed distorted.

Some of our findings correlate with the literature. Ragini (2012) also underlined the impact of net sales in Japan. The importance of public listing had been found outstanding in an earlier study (Kovács, 2015), while sectoral categorisation was a new element. However, our preliminary expectations linked to the book value of intangible assets or their relative value in proportion to the balance sheet total were not met as opposed to the findings published by Lippai-Makra et al. (2019). 


\section{SUMMARY}

Applying content analysis, our study has revealed the reporting culture of Hungarian companies of the highest sales regarding intangible assets. We took the list of items from an earlier study on an international sample, and we assigned scores to the different enterprises after detailed reading of their reports. We have found that the scores had a moderate average rise in between the two studied accounting years, which was much lower than the average growth rate found in literature. With respect to the topic of the data disclosed, you can find that enterprises communicated most intensively about intellectual property, goodwill, the intangible items in their balance sheets, and environmental and other factors. Items in the categories of market and customers, corporate and shareholder information, and strategy and competition were less emphatic. Enterprises were the least communicative on topics of human resources and research and development. We have also drawn the conclusion that the regulations of the Accounting Act significantly affected the reporting culture of the Hungarian enterprises on intangible resources as also reflected in the data five years later.

In our study, we have identified the factors having a demonstrable effect on the reporting practice of the companies in the sample. This study has also confirmed our earlier findings regarding the decisive part played by public listing. A novelty of this study has been the identification of net sales and sectoral category to be factors defining reporting practice, however, our preliminary expectations related to the net value of intangible assets or their relative value in proportion to the balance sheet total have not been met.

Regarding the intensity of disclosure, listed enterprises making their business reports accessible typically reached outstanding scores. The publication of those documents online is of key importance from the aspect of intangible assets; it may be worth expanding the current regulations to also cover other large corporates not publicly listed. We may assume that enterprises above a certain company size (net sales) do have stakeholders who could make good use of such information in business reports. The publication of management reports in such a way could increase awareness of reporting and could motivate voluntary disclosure too.

The limitations of our study originate in the methodology applied: Castilla-Polo-Ruiz-Rodríguez (2017) underlined the two major setbacks of content analysis. One is the lack of comparability: even if two researchers follow the same list of items, the comparability of their results is limited because of the human interpretation of the information and the context. Another obstacle to our analysis is the group of the reports studied: most similar studies analyse the content of annual reports as seen in the study mentioned earlier. We can envisage that other forms of communication used by companies can be included in research in future, such 
as sustainability reports, company websites or even information published on social media. Increasing the number of items in the sample or generating an international sample could improve our work to reveal country specific differences by applying further statistical methods. In any case, content analysis should be supplemented with other qualitative methods to gain insight into the motivating factors behind disclosure.

\section{ANNEXES}

\section{Annex 1}

\section{Ragini's (2012) items}

\begin{tabular}{ll}
\hline & Items/Year \\
\hline A. & Research and Development \\
\hline a1 & R \& D Facilities \\
\hline a2 & R \& D Activities \\
\hline a3 & R \& D Personnel \\
\hline a4 & R \& D Focus Areas \\
\hline a5 & R \& D Centres/ Bases \\
\hline a6 & R \& D Structure \\
\hline a7 & R \& D Efforts/Initiatives \\
\hline a8 & R \& D Results/Achievements \\
\hline a9 & R \& D Expenditure \\
\hline a10 & R \& D Expenditure as \% of Sales \\
\hline a11 & Growth Rate of R\&D \\
\hline Expenditure \\
\hline a12 & $\begin{array}{l}\text { Reason for the Increase or } \\
\text { Decrease in Expenditure }\end{array}$ \\
\hline a13 & Information on Accounting \\
Treatment of R\&D Expenditure \\
\hline a14 & $\begin{array}{l}\text { In-process Research and } \\
\text { Development }\end{array}$ \\
\hline a15 & Technology and Innovation \\
\hline a16 & Technical know-How \\
\hline a17 & New Technologies \\
\hline a18 & $\begin{array}{l}\text { Details Regarding Funding } \\
\text { of R\&D }\end{array}$ \\
\hline a19 & Information Technology \\
\hline
\end{tabular}

\begin{tabular}{ll}
\hline & Items/Year \\
\hline a20 & $\begin{array}{l}\text { Information Related } \\
\text { to Software Cost }\end{array}$ \\
\hline & Grand Total (A) \\
\hline B. & Strategy \& Competition \\
\hline & Strategy: \\
\hline b1 & R \& D Strategy \\
\hline b2 & Human Resource Strategy \\
\hline b3 & Intellectual Property Strategy \\
\hline b4 & Product Strategy \\
\hline b5 & Marketing Strategy \\
\hline b6 & Growth Strategy \\
\hline b7 & Growth Areas/Drivers \\
\hline b8 & Business Strategy \\
\hline b9 & Suppliers Strategy \\
\hline b10 & Investment Strategy \\
\hline b11 & Global Strategy \\
\hline b12 & Regional Strategy \\
\hline b13 & Leadership Strategy \\
\hline b14 & Strengths \\
\hline b15 & Risk Management \\
\hline b16 & Liquidity Management \\
\hline b17 & Strategic Issues \\
\hline b18 & Strategic Targets \\
\hline b19 & Strategic Initiatives \\
\hline b20 & Restructuring Activities \\
\hline & \\
\hline
\end{tabular}




\begin{tabular}{|c|c|}
\hline & Items/Year \\
\hline b21 & Strategic Alliances \\
\hline b22 & $\begin{array}{l}\text { Cost Control Measures / } \\
\text { Initiatives }\end{array}$ \\
\hline b23 & Financial Strategies \\
\hline \multirow[t]{2}{*}{ b24 } & $\begin{array}{l}\text { Information Related to Supply } \\
\text { Chain Management }\end{array}$ \\
\hline & Competition: \\
\hline b25 & Type/Degree of Competition \\
\hline b26 & Competitive Factors \\
\hline b27 & Key Competitors \\
\hline b28 & Industry Trends/Environment \\
\hline b29 & Risk Factors \\
\hline \multirow[t]{2}{*}{ b30 } & $\begin{array}{l}\text { Efforts to Overcome Global } \\
\text { Competition }\end{array}$ \\
\hline & Grand Total (B) \\
\hline \multirow[t]{2}{*}{ C. } & Market and Customer \\
\hline & Market: \\
\hline $\mathrm{cl}$ & Primary Markets \\
\hline c2 & Major Products \\
\hline c3 & New Products \\
\hline c4 & $\begin{array}{l}\text { Ratio of New Products to all } \\
\text { Products }\end{array}$ \\
\hline c5 & Market Units/Stores \\
\hline c6 & No. of New Units/Stores \\
\hline c7 & New Markets/Target Markets \\
\hline c8 & Market Risk \\
\hline c9 & Market Share \\
\hline $\mathrm{c} 10$ & Marketing/Advertising Costs \\
\hline $\mathrm{c} 11$ & Market Growth \\
\hline $\mathrm{c} 12$ & Brand Names \\
\hline $\mathrm{c} 13$ & Top Brands \\
\hline c14 & $\begin{array}{l}\text { Information Related to } \\
\text { Distribution }\end{array}$ \\
\hline c15 & No. of Dealers \\
\hline $\mathrm{c} 16$ & Major Suppliers \\
\hline $\mathrm{c} 17$ & Supplier Relationships \\
\hline
\end{tabular}

\begin{tabular}{|c|c|}
\hline & Items/Year \\
\hline $\mathrm{c} 18$ & $\begin{array}{l}\text { Sales of Company as \% of } \\
\text { Industry Sales }\end{array}$ \\
\hline c19 & Market leadership \\
\hline c20 & No. of Brands \\
\hline c21 & Brand Value \\
\hline$c 22$ & Brand Building \\
\hline c23 & $\begin{array}{l}\text { Sales Promotion/Marketing } \\
\text { Activities }\end{array}$ \\
\hline c24 & $\begin{array}{l}\text { Per Capita Consumption of } \\
\text { Product }\end{array}$ \\
\hline c25 & $\begin{array}{l}\text { Information Related to Product } \\
\text { Quality }\end{array}$ \\
\hline \multirow[t]{2}{*}{ c26 } & $\begin{array}{l}\text { Information Related to Product } \\
\text { Design }\end{array}$ \\
\hline & Customer: \\
\hline c27 & Customer Base \\
\hline c28 & Major/Significant Customers \\
\hline c29 & New Customers \\
\hline c30 & Customer Loyalty \\
\hline c31 & Customer Relationships \\
\hline c32 & Customer List \\
\hline c33 & Geographic Division \\
\hline c34 & Sales Incentives with Customers \\
\hline c35 & $\begin{array}{l}\text { Information on Customer } \\
\text { Satisfaction }\end{array}$ \\
\hline \multirow[t]{2}{*}{ c36 } & Customer Services \\
\hline & Grand Total (C) \\
\hline D. & Human Resource \\
\hline d1 & No. of Employees \\
\hline $\mathrm{d} 2$ & No. of Employees(segment-wise) \\
\hline $\mathrm{d} 3$ & No. of Employees(area-wise) \\
\hline $\mathrm{d} 4$ & New employees \\
\hline $\mathrm{d} 5$ & AgeProfile of Employees \\
\hline d6 & Average age of Employees \\
\hline d7 & $\begin{array}{l}\text { Gender Classification of } \\
\text { Employees }\end{array}$ \\
\hline $\mathrm{d} 8$ & Educational Index of Employees \\
\hline
\end{tabular}




\begin{tabular}{|c|c|}
\hline & Items/Year \\
\hline d9 & Value of Human Resource \\
\hline $\mathrm{d} 10$ & $\begin{array}{l}\text { Value of Human Resource per } \\
\text { Employee }\end{array}$ \\
\hline d11 & $\begin{array}{l}\text { Return on Human Resource } \\
\text { Value }\end{array}$ \\
\hline $\mathrm{d} 12$ & Training Programmes \\
\hline d13 & $\begin{array}{l}\text { Human Resource Development } \\
\text { Activities }\end{array}$ \\
\hline $\mathrm{d} 14$ & Leadership Team \\
\hline $\mathrm{d} 15$ & $\begin{array}{l}\text { Recruiting and Staffing } \\
\text { Programmes }\end{array}$ \\
\hline $\mathrm{d} 16$ & Employee Relationships \\
\hline $\mathrm{d} 17$ & Industrial Relations \\
\hline $\mathrm{d} 18$ & Remuneration Policy \\
\hline d19 & $\begin{array}{l}\text { Particulars of Remuneration and } \\
\text { Benefits Paid to key Managerial } \\
\text { Personnel }\end{array}$ \\
\hline $\mathrm{d} 20$ & Incentive Plans for Employees \\
\hline $\mathrm{d} 21$ & Retirement Benefits \\
\hline $\mathrm{d} 22$ & $\begin{array}{l}\text { Employment Productivity Over } \\
\text { Years }\end{array}$ \\
\hline $\mathrm{d} 23$ & $\begin{array}{l}\text { No. of Employees Exposed to } \\
\text { Training programmes }\end{array}$ \\
\hline $\mathrm{d} 24$ & $\begin{array}{l}\text { Information on Employee } \\
\text { Satisfaction }\end{array}$ \\
\hline $\mathrm{d} 25$ & $\begin{array}{l}\text { Information about Executive } \\
\text { Officers }\end{array}$ \\
\hline \multirow[t]{2}{*}{$\mathrm{d} 26$} & Sales per Employee \\
\hline & Grand Total (D) \\
\hline E. & $\begin{array}{l}\text { Intellectual Property Rights } \\
\text { \& Goodwill and Other } \\
\text { Intangible Assets }\end{array}$ \\
\hline & Intellectual Property Rights: \\
\hline e1 & $\begin{array}{l}\text { Value of Intellectual Property } \\
\text { Rights }\end{array}$ \\
\hline $\mathrm{e} 2$ & No. of Patents \\
\hline e3 & No. of Patents (area-wise) \\
\hline $\mathrm{e} 4$ & Value of Patents \\
\hline e5 & Value of Acquired Patents \\
\hline
\end{tabular}

\begin{tabular}{|c|c|}
\hline & Items/Year \\
\hline e6 & Patent Ranking \\
\hline e7 & $\begin{array}{l}\text { Value of Trademarks/ } \\
\text { Tradenames }\end{array}$ \\
\hline e8 & $\begin{array}{l}\text { Names of Trademarks Registered } \\
\text { for the Company }\end{array}$ \\
\hline e9 & Intellectual Property Cycle \\
\hline $\mathrm{e} 10$ & Intellectual Property Activities \\
\hline e11 & $\begin{array}{l}\text { Intellectual Property } \\
\text { Management }\end{array}$ \\
\hline e12 & $\begin{array}{l}\text { Information on Trade Secrets, } \\
\text { Copyrights etc. }\end{array}$ \\
\hline \multirow[t]{2}{*}{$\mathrm{e} 13$} & Value of Customer Relationships \\
\hline & $\begin{array}{l}\text { Goodwill and other } \\
\text { Intangible Assets: }\end{array}$ \\
\hline e14 & Value of Goodwill \\
\hline e15 & Value of Acquired Goodwill \\
\hline e16 & $\begin{array}{l}\text { Value of Goodwill } \\
\text { (Segment-wise) }\end{array}$ \\
\hline $\mathrm{e} 17$ & Value of Goodwill (Area-wise) \\
\hline $\mathrm{e} 18$ & Value of Other Intangible Assets \\
\hline e19 & $\begin{array}{l}\text { Items Included in Other } \\
\text { Intangible Assets }\end{array}$ \\
\hline e20 & $\begin{array}{l}\text { Accounting Treatment for } \\
\text { Goodwill and Other Intangible } \\
\text { Assets }\end{array}$ \\
\hline e21 & $\begin{array}{l}\text { Amortization Method for } \\
\text { Goodwill and other Intangible } \\
\text { Assets }\end{array}$ \\
\hline $\mathrm{e} 22$ & $\begin{array}{l}\text { Amortization Period for } \\
\text { Goodwill and Other Intangible } \\
\text { Assets }\end{array}$ \\
\hline e23 & $\begin{array}{l}\text { Amortized Value for Goodwill } \\
\text { and Other Intangible Assets }\end{array}$ \\
\hline e24 & $\begin{array}{l}\text { Carrying Value for Goodwill and } \\
\text { Other Intangible Assets }\end{array}$ \\
\hline e25 & $\begin{array}{l}\text { Details Regarding Impairment } \\
\text { Test Criteria for Goodwill and } \\
\text { Other Intangible Assets }\end{array}$ \\
\hline & Grand Total (E) \\
\hline
\end{tabular}




\begin{tabular}{ll}
\hline & Items/Year \\
\hline F. & $\begin{array}{l}\text { Corporate \& Shareholder } \\
\text { Information }\end{array}$ \\
\hline & Corporate Information: \\
\hline f1 & Corporate Values \\
\hline f2 & Corporate Goals/Objectives \\
\hline f3 & Corporate Vision \\
\hline f4 & Corporate Mission \\
\hline f5 & Corporate Culture \\
\hline f6 & Corporate Profile \\
\hline f7 & Corporate Philosophy \\
\hline f8 & Corporate History \\
\hline f9 & Corporate Accomplishments \\
\hline f10 & Corporate Structure \\
\hline f11 & Corporate Data \\
\hline f12 & $\begin{array}{l}\text { Corporate Ethics/ } \\
\text { Code of Conduct }\end{array}$ \\
\hline & Shareholder information: \\
\hline f13 & Shareholder Complaints \\
\hline f14 & No. of Shareholders \\
\hline f15 & $\begin{array}{l}\text { Shareholding Distribution (type } \\
\text { of shareholder) }\end{array}$ \\
\hline f16 & $\begin{array}{l}\text { Shareholding Distribution } \\
\text { (number of shares held) }\end{array}$ \\
\hline f17 & Share Price Data \\
\hline f18 & Major Shareholders \\
\hline & Grand Total (F) \\
\hline G. & Environment \& Others \\
\hline & Environment: \\
\hline Environmental Activities \\
\hline Environmental Philosophy \\
\hline Ro Ro
\end{tabular}

\begin{tabular}{ll}
\hline & Items/Year \\
\hline g3 & $\begin{array}{l}\text { Environmental Programmes/ } \\
\text { Policies }\end{array}$ \\
\hline g4 & Environmental Initiatives \\
\hline g5 & Environmental Commitments \\
\hline g6 & Environmental Management \\
\hline F7 & Environmental Matters \\
\hline g8 & Environmental Expenditure \\
\hline g9 & Products/Technologies \\
\hline & Contributing to Environment \\
\hline g10 & Corporate Social Responsibility \\
\hline g11 & Corporate Governance \\
\hline g12 & Contingencies \& Commitments \\
\hline g13 & Off Balance Sheet Arrangements \\
\hline g14 & Lease \\
\hline g15 & Related Party Transactions \\
\hline g16 & Hedging Activities \\
\hline g17 & Fair Value of Financial \\
\hline g18 & Contractual Obligations \\
\hline g19 & New Accounting Standards \\
\hline g20 & Accounting Changes \\
\hline g21 & Outlook/ Future \\
\hline g22 & Subsequent Events \\
\hline g23 & Opportunities and Challenges \\
\hline g24 & Information on Awards \\
\hline g25 & Information on Credit Ratings \\
\hline & Grand Total (G) \\
\hline
\end{tabular}

Source: Ragini (2012:69-71) 


\section{Annex 2}

In the $\mathrm{M}$ estimation, the goal is to minimise function $\rho$ of the error: $\hat{\beta}_{M}=\min _{\beta} \sum_{i=1}^{n} \rho\left(\frac{e_{i}}{\sigma}\right)=\min _{\beta} \sum_{i=1}^{n} \rho\left(\frac{y_{i}-\sum_{j=0}^{k} x_{i, j} \beta_{j}}{\sigma}\right)$, while scale parameter $\hat{\sigma}$ can be estimated using $\hat{\sigma}=\frac{\text { median } \mid e_{i}-\text { median }\left(e_{i}\right) \mid}{0.6745}$. Connecting the weighting function of $\hat{\beta}_{M}$ the first partial derivation of to the target function of Tukey's-b $\left(w\left(e_{i}\right)=\frac{\rho \frac{y_{i}-\sum_{j=0}^{k} x_{i, j} \beta}{\hat{\sigma}}}{\frac{y_{i}-\sum_{j=0}^{k} x_{i, j} \beta}{\widehat{\sigma}}}\right)$, you get the weighting function $\left(w_{i}=\left\{\begin{array}{c}\left.\left[1-\left(\frac{u_{i}}{c}\right)^{2}\right]^{2}, \text { if }\left|u_{i}\right| \leq 4.685\right) . \\ 0, \text { if }\left|u_{i}\right|>4.685\end{array}\right.\right.$

\section{REFERENCES}

Albu, N. - Albu, C. N. - Filip, A. (2017): Corporate Reporting in Central and Eastern Europe: Issues, Challenges and Research Opportunities. Accounting in Europe 14, 249-26o. https://doi.or g/10.1080/17449480.2017.1385819.

Bellora, L. - Guenther, T. W. (2013): Drivers of innovation capital disclosure in intellectual capital statements: Evidence from Europe. The British Accounting Review 45, 255-270. https://doi. org/10.1016/j.bar.2013.06.002.

BodA, György - RÉvész, TAmás - LosoncI, DÁvid - FülöP, Zoltán (2019): A növekedési ütem és a foglalkoztatás növelésének lehetőségeiről [On growth rate and the possibility to increase employment]. Közgazdasági Szemle 66, 376-417. https://doi.org/10.18414/KSZ.2019.4.376.

Bogdan, V. - Platon, J. - PopA, D. N. (2011): Intellectual capital reporting and disclosure in the annual reports of romanian manufacturing listed companies - Methodology and discussion of results. Annals of Faculty of Economics 1, 466-476. http://anale.steconomiceuoradea.ro/volume/2011/n2/065.pdf.

Boujelbene, M. A. - Affes, H. (2013): The impact of intellectual capital disclosure on cost of equity capital: A case of French firms. Journal of Economics Finance and Administrative Science 18, 45-53. https://doi.org/10.1016/S2077-1886(13)70022-2.

Brand Finance (2018): Global Intangible Finance Tracker (GIFT).

Castilla-Polo, F. - Ruiz-Rodríguez, C. (2017): Content analysis within intangible assets disclosure: a structured literature review. Journal of Intellectual Capital 18, 506-543. https://doi. org/10.1108/JIC-11-2016-0123.

CsEndes, Csilla (2014): Szimmetrikus stabil eloszlások paramétereinek egy robusztus becslési eljárása és alkalmazása [A robust estimation and its use for parameters of symmetric stable distributions]. PhD Dissertation, Hatvany József Informatikai Tudományok Doktori Iskola, Miskolci Egyetem. http://midra.uni-miskolc.hu:8o/?docId=19054.

FEgYVERnEKI, SÁndor (2003): Robust estimators and probability integral transformations. Mathematical and Computer Modelling, Hungarian Applied Mathematics 38(7-9), 803-814. https:// doi.org/10.1016/So895-7177(03)90065-3. 
Feng, C. - WAng, H. - Lu, N. - Chen, T. - He, H. - Lu, Y. - Tu, X. M. (2014): Log-transformation and its implications for data analysis. Shanghai Arch Psychiatry 26, 105-109. https://doi.org/10.3969/j. issn.1002-0829.2014.02.009.

Figyelő (2018): Figyelő Top 200: Magyarországi legnagyobb cégei [Largest companies in Hungary], 2018.

Figyelő (2013): Figyelő Top 200: Magyarországi cégek ranglistái [Ranking of Hungarian companies].

Gambetti, R. C. - Melewar, T. C. - Martin, K. D. (2017): Guest Editors' Introduction: Ethical Management of Intangible Assets in Contemporary Organizations. Business Ethics Quarterly 27, 381-392, https://doi.org/10.1017/beq.2017.21.

Ho, H. - Chau, K. - Cheung, P. (2012): Intellectual Capital Disclosure and Initial Public Offerings: Evidence from Hong Kong. Journal of Applied Economics and Business Research 2(2), 56-68. https://pdfs.semanticscholar.org/d6e7/ed 47763fa5c8ffo253d54ccf843baefoo 738 .pdf.

Juhász, PÉTer (2016): Management under Limited Information - The Measurement of Off-Balance Sheet Assets at Hungarian firms. Central European Business Review 5, 23-33. https://doi. org/10.18267/j.cebr.164.

Kornacki, A. - Bochniak, A. (2015): The use of outlier detection methods in the log-normal distribution for the identification of atypical varietal experiments. Biometrical Letters 52, 75-84. https://doi.org/10.1515/bile-2015-0007.

Kovács, Zsuzsanna Ilona (2015): Immateriális vagyonelemek a magyar számviteli rendszerben és a beszámolókban [Intangible assets in the Hungarian accounting system and reports]. Pénzügyi Szemle 6o, 231-242. https:/www.penzugyiszemle.hu/documents/kovacszs-2015-2-mpdf_20170817154649_91.pdf.

KPMG International (2020): The Time Has Come: The KPMG Survey of Sustainability Reporting 2020. https://home.kpmg/xx/en/home/insights/2020/11/the-time-has-come-survey-of-sustainability-reporting.html.

LAÁв ÁGNEs (2010): Kompetencia-ga(rá)zdálkodás I. [(Mis)use of competence management I.] Budapesti Müszaki és Gazdaságtudományi Egyetem, Budapest: Typotex Kiadó.

LeV, B. (2003): Remarks on the Measurement, Valuation, and Reporting of Intangible Assets. Economic Policy Review 9(3), 17-22. https://papers.ssrn.com/sol3/papers.cfm?abstract_id=1280689.

Li, J. - Pike, R. - Haniffa, R. (2008): Intellectual capital disclosure and corporate governance structure in UK firms. Accounting and Business Research 38, 137-159. https://doi.org/10.1080/ooo147 88.2008.9663326.

LipPAi-MAKRA, Edit - RÁdóczi Zsolt - KovÁcs Zsuzsanna Ilona (2019): Intellectual capital disclosure of Hungarian and Czech Listed firms. European Financial and Accounting Journal 14, 43-59. https://doi.org/10.18267/j.efaj.229.

Novák, M. (2018): The Quality of Disclosure under IAS 38 in Financial Statements of Entities Listed on PSE. European Financial and Accounting Journal 2018, 31-44. https://doi.org/10.18267/j. efaj.208.

OECD (2012): Corporate Reporting of Intangible Assets: A Progress Report. https://www.oecd.org/ daf/ca/Intangible\%2oAssets.pdf.

Oliveira, L. - Rodrigues, L. - Craig, R. (2006): Firm-specific determinants of intangibles reporting: evidence from the Portuguese stock market. Journal of Human Resource Costing \& Accounting 10, 11-33. https://doi.org/10.1108/14013380610672657.

OrhangazI, Ö. (2019): The role of intangible assets in explaining the investment-profit puzzle. Cambridge Journal of Economics 43, 1251-1286. https://doi.org/10.1093/cje/beyo46.

Petty, R. - Cuganesan, S. - Finch, N. - Ford, G. (2009): Intellectual Capital and Valuation: Challenges in the Voluntary Disclosure of Value Drivers. SSRN Electronic Journal. https://doi. org/10.2139/ssrn.1490208 
RaGinI, J. R. (2012): Corporate Disclosure of Intangibles: A Comparative Study of Practices among Indian, US, and Japanese Companies. Vikalpa 37, 51-72. https://doi.org/10.1177/0256090920120305.

Rousseeuw, P. - Yohai, V. (1984): Robust Regression by Means of S-Estimators. In Franke, J. Härdle, W. - Martin, D. [eds.] (1984): Robust and Nonlinear Time Series Analysis, Lecture Notes in Statistics. New York: Springer US, 256-272. https://doi.org/10.1007/978-1-4615-7821-5_15.

SAXné, ANdor Ágnes MÁrta (2014): Az immateriális javak számviteli elmélete és alkalmazása a magyar szabályozási rendszerben. PhD-értekezés. http://phd.lib.uni-corvinus.hu/774/.

Sheh AtA, N. F. (2014): Theories and Determinants of Voluntary Disclosure. Accounting and Finance Research 3. https://doi.org/10.5430/afr.v3n1p18.

Susanti, Y. - Pratiwi, H. - Sulistijowati H. S. - Liana, T. (2014): M estimation, S estimation, and MM estimation in robust regression. International Journal of Pure and Apllied Mathematics 91, 349-36o. https://doi.org/10.12732/ijpam.v91i3.7.

Sveıby, K. E. (2001): Szervezetek új gazdagsága: a menedzselt tudás. Budapest: KJK-KERSZÖV.

TAKÁCs, SzA BOLCS (2012): Érzékenységvizsgálatok a statisztikai eljárásokban. Alkalmazott Matematikai Lapok 29, 67-100. http://aml.math.bme.hu/wp-content/uploads/2012/o6/29-Tak\%C3\%A1cs. pdf.

Wooldridge, J. M. (2010): Econometric Analysis of Cross Section and Panel Data, Second Edition.| Cambridge: The MIT Press.

YAng, T. - Gallagher, C. M. - McMahan, C. S. (2019): A robust regression methodology via Mestimation. Communications in Statistics - Theory and Methods 48, 1092-1107. https://doi.org/1 $0.1080 / 03610926.2018 .1423698$.

Zambon, S. - Marzo, G. -Girella, L. -Abela, M. - D’Albore, N. (2020): A literature review on the reporting of intangibles. Academic Report. https://www.efrag.org/Assets/Download?assetU $\mathrm{rl}=\% 2$ Fsites\%2Fwebpublishing\%2FSiteAssets\%2FA\%252oliterature\%252oreview\%2520on\%2520t he\%252oreporting\%2520of\%252ointangibles.pdf. 